\title{
KAJIAN DUKUNGAN KEAHLIAN DAN STAFF AHLI DI ANGGOTA DEWAN PERWAKILAN DAERAH REPUBLIK INDONESIA
}

\author{
OLEH:
}

\author{
TAHEGGA PRIMANANDA ALATH ${ }^{1}$ \\ DAN \\ WORO WINANDI ${ }^{2}$
}

\begin{abstract}
ABSTRAK
Putusan Mahkamah Konstitusi Nomor 92/PUU-X/2012 dan dan Undang-Undang Nomor 17 Tahun 2014 tentang Majelis Pewmusyawaratan Rakyat, Dewan Perwakilan Rakyat, Dewan Perwakilan Daerah, dan Dewan Perwakilan Rakyat Daerah (UU MD3) menjadi babak baru dalam perkembangan Hukum Tata Negara di Indonesia, khususnya terhadap format kelembagaanya. Penguatan kewenangan DPD memiliki tantangan tersendiri dalam kondisi internalnya dalam hal ini adalah sumber daya manusianya (dukungan keahlian dan staff ahli). Jika kewenangan yang dimiliki DPD tidak dibarengi dengan kapabilitas DPD dalam menjalankan tugas dan fungsi, maka sekuat apapun kewenangan yang dimiliki DPD akan menjadi hal yang percuma. Peningkatan kapabilitas DPD dalam menjalankan tugas dan fungsinya menjadi sebuah wacana yang urgen untuk diteliti dan dikeluarkan solusi atas hal tersebut.

Jenis penelitian yang digunakan adalah yuridis-empiris, dengan maksud dan tujuan untuk menemukan fakta (fact-finding), kemudian diteruskan dengan menemukan masalah (problem-finding), kemudian mengidentifikasi masalah (problem-identification), dan kemudian mencari penyelesaian dari masalah (problem-solution). Maka pendekatan yang digunakan dalam penelitian ini adalah pendekatan sosiologis. Teknik analisis yang digunakan adalah deskriptif-kualitatif, yaitu memberikan pemaparan peran dan fungsi DPD RI, kemudian kondisi kekinian anggota DPD RI dalam menjalankan peran dan fungsinya kemudian dianalisis dan dicari sebuah kesimpulan.

Kata Kunci: Kewenangan, Prinsip Check and Balances, Tugas dan Fungsi Dewan Perwakilan Daerah
\end{abstract}

\section{PENDAHULUAN}

Dewan Perwakilan Daerah secara kelembagaan merupakan sebuah lembaga Negara baru yang terbentuk dari amandemen ketiga dan keempat Undang-Undang Dasar Negara Republik Indonesia Tahun 1945. Dasar pembentukan lembaga ini adalah perubahan ketiga UUD NRI Tahun 1945 yakni dalam pasal 22C, 22D dan 22 E. Pembentukan Dewan Perwakilan Daearah Republik Indonesia (DPD) merupakan upaya untuk merestrukturisasi bangunan parlemen Indonesia menjadi dua kamar (bikameral). ${ }^{3}$

DPD sebagai bentuk kamar kedua dari lembaga parlemen nampaknya berbentuk setengah hati. Kewenangan yang dimiliki oleh DPD hanyalah terbatas, berbeda halnya dengan kewenangan yang dimiliki Dewan Perwakilan Rakyat, khususnya dalam bidang legislasi.

\footnotetext{
${ }^{1}$ Dosen Hukum Tata Negara Universitas Narotama Surabaya

2 Dosen Hukum

${ }^{3}$ Jimly Asshiddiqie, Format Kelembagaan Negara dan Pergeseran Kekuasaan dalam UUD 1945, FH UII Press, Yogyakarta, 2004, h.17.
} 
Ketentuan dalam Undang-Undang Nomor 27 Tahun 2009 tentang Majelis Pewmusyawaratan Rakyat, Dewan Perwakilan Rakyat, Dewan Perwakilan Daerah, dan Dewan Perwakilan Rakyat Daerah (UU MD3), dan Undang-Undang Nomor 12 Tahun 2011 tentang Pembentukan Peraturan Perundangan-Undangan (UU PPP) membuat DPD seolah adalah bayangan dari DPR. DPD hanya berwenang mengajukan dan membahas Rancangan Undang-Undang dibidang tertentu saja yang disebut secara enumerative dalam Undang-Undang Dasar Negara Republik Indonesia tahun 1945. ${ }^{4}$

Putusan Mahkamah Konstitusi Nomor 92/PUU-X/2012 dan Undang-Undang Nomor 17 Tahun 2014 tentang Majelis Permusyawaratan Rakyat, Dewan Perwakilan Rakyat, Dewan Perwakilan Daerah, dan Dewan Perwakilan Rakyat Daerah (UU MD3) menjadi babak baru dalam perkembangan Hukum Tata Negara di Indonesia, khususnya terhadap format kelembagaanya. Putusan Mahkamah Konstitusi tersebut setidaknya bisa diartikan sebagai bentuk amandemen terhadap Undang-Undang Negara Republik Indonesia Tahun 1945 (UUD NRI 1945) mengenai diperkuatnya kewenangan yang dimiliki Dewan Perwakilan Daerah (DPD). Mahkamah Konstitusi menafsirkan frasa "dapat mengajukan" dalam Pasal 22D ayat (1) merupakan sebuah pilihan ataupun hak/ kewenangan dalam mengajukan rancangan undang-undang, dan "ikut membahas" dalam Pasal 22D ayat (2) UUD NRI 1945 inipun diartikan bahwa DPD memiliki kewenangan untuk ikut membahas rancangan undang-undang yang berkaitan dengan otonomi daerah, hubungan pusat dan daerah, pembentukan pemekaran dan penggabungan daerah, pengelolaan sumber daya alam dan sumber daya lainnya, serta perimbangan keuangan pusat dan daerah bersama dengan Dewan Perwakilan Rakyat (DPR).

Penguatan kewenangan DPD memiliki tantangan tersendiri dalam kondisi internalnya dalam hal ini adalah sumber daya manusianya (dukungan keahlian dan staff ahli). Jika kewenangan yang dimiliki DPD tidak dibarengi dengan kapabilitas DPD dalam menjalankan tugas dan fungsi, maka sekuat apapun kewenangan yang dimiliki DPD akan menjadi hal yang percuma. Peningkatan kapabilitas DPD dalam menjalankan tugas dan fungsinya menjadi sebuah wacana yang urgen untuk diteliti dan dikeluarkan solusi atas hal tersebut. Solusi yang ditawarkan juga harus secara komperhensif, sehingga mampu menghasilkan produk keluaran DPD pada bidang legislasi, pengawasan, dan keuangan dapat dipertanggungjawabkan secara akuntabel, professional, dan modern kepada rakyat.

Berdasarkan pemaparan pada latar belakang tersebut, maka dalam penelitian ini mengambil rumusan masalah sebagai berikut:

1. Mengapa DPD dalam menjalankan tugas dan fungsinya perlu ditingkatkan kemampuannya?

2. Apa kendala yang dihadapi DPD dalam menjalankan tugas dan fungsinya?

3. Bagaimana upaya yang dilakukan dalam meningkatkan kemampuan DPD dalam menjalankan tugas dan fungsinya?

\section{PEMBAHASAN}

\section{Urgensi Peningkatan Kemampuan Dewan Perwakilan Daerah Republik Indonesia Dalam Menjalankan Tugas Dan Fungsinya}

Dewan Perwakilan Daerah Republik Indonesia (DPD RI) merupakan lembaga negara yang terbentuk pada masa reformasi di tahun 1998, sebagai tuntutan atas membentuk badan legislasi bikameral yang memperhatikan aspirasi daerah di Indonesia. Secara historis pengaturan kelembagaan DPD RI tidak dapat dipisahkan dari keberadaan utusan golongan pada masa Orde Baru. Kiprah adanya utusan golongan dalam tubuh MPR tersebut didasari oleh sebuah pemikiran filosofis bahwa dalam MPR, keberadaan lembaga yang mewakili

\footnotetext{
${ }^{4}$ Ni'matul Huda, Lembaga Negara dalam Masa Transisi Demokrasi, UII Press, Yogyakarta, 2007, h.99.
} 
kepentingan daerah secara wilayah, sebagai pencerminan dari penyuara kepentingan daerah dalam penentuan arah kebijakan Negara ${ }^{5}$. Namun pembentukan kebijakan tersebut, oleh sebagian kalangan dianggap tidak cukup menggambarkan tujuan pembentukan secara nyata. Terdapat beberapa alasan meniadakan utusan golongan, yaitu: pertama, kesulitan dalam menemukan golongan yang berhak sebagai wakil di MPR; kedua, telah terjadi penyalahgunaan wewenang menentukan dan mengangkat utusan golongan, banyak utusan golongan yang kemudian memiliki afiliasi dengan partai politik, dan tidak memperjuangkan kepentingan golongannya. ${ }^{6}$

Keberadaan utusan golongan dalam keanggotaan MPR berasal dari diadopsinya pengertian sistem perwakilan fungsional dalam konstitusi. Utusan golongan oleh founding constitution dipandang sebagai golongan-golongan ekonomi seperti gerakan koperasi, yang dianggap sebagai cerminan dari kedaulatan rakyat di bidang ekonomi. Asumsinya adalah bahwa kepentingan seluruh rakyat tidak cukup diwakili secara politik melalui pemilihan umum yang mengutamakan partai politik. founding constitution berusaha mengintegrasikan pemahaman yang tidak utuh tentang demokrasi. Dalam tradisi liberal barat, demokrasi cenderung hanya dilihat dari segi politik, sementara dalam tradisi sosialis, kedaulatan rakyat cenderung dipahami secara ektrim sebagai ideologi ekonomi. UUD 1945 mencoba mengakomodir dua konsepsi tersebut yaitu, menerima prinsip demokrasi dan hak asasi manusia, juga menerima demokrasi dan paham negara kesejahteraan. ${ }^{7}$

Pembentukan DPD RI dimulai dari keberadaan amandemen ketiga dan keempat Undang-undang Dasar Negara Republik Indonesia Tahun 1945 (UUD NRI Tahun 1945) Pasal 22C, 22D dan 22E yang merupakan dasar pembentukan lembaga yang secara fungsi diharapkan dapat menjadi representasi kepentingan daerah. DPD RI mencerminkan keterwakilan politik daerah di tingkat pusat, dengan keanggotaannya masing-masing 4 orang keterwakilan dari setiap Provinsi diseluruh Indonesia yang dipilih secara langsung dalam agenda pemilihan umum setiap 5 tahun sekali.

Pada dasarnya pembentukan DPD RI juga bertujuan untuk membangun sistem bikameral yang kuat dan efektif, walaupun jika dilihat pada kenyataannya sampai hari ini DPD RI masih bersifat weak bicameral. Pembangunan sistema bikameral yang efektif yang dimaksudkan adalah DPD RI mampu menjadi penyeimbang dari Dewan Perwakilan Rakyat Republik Indonesia (DPR RI) dalam setiap pengambilan kebijakan di tingkat nasional, khususnya berkaitan dengan pembentukan perundang-undangan. Artinya DPD RI dimaksudkan untuk menciptakan mekanisme penyelenggaraan parlemen sesuai dengan prinsip checks and balances, dan dalam relasi hubungan yang lebih luas antara eksekutif dan legislatif.

Ketentuan dalam UUD NRI Tahun 1945 yang memberi kewenangan kepada DPD RI adalah:

a. Mengajukan kepada DPR RI rancangan undang-undang yang berkaitan dengan otonomi daerah, hubungan pusat dan daerah, pembentukan dan pemekaran serta penggabungan daerah, pengelolaan sumber daya alam dan sumber daya ekonomi lainnya, serta yang berkaitan dengan perimbangan keuangan pusat dan daerah. (Pasal 22D ayat (1))

b. Ikut membahas rancangan undang-undang yang berkaitan dengan otonomi daerah; hubungan pusat dan daerah; pembentukan, pemekaran, dan penggabungan daerah; pengelolaan sumber daya alam dan sumber daya ekonomi lainnya, serta perimbangan keuangan pusat dan daerah; serta memberikan pertimbangan kepada DPR RI atas rancangan undang-undang anggaran pendapatan dan belanja negara dan rancangan

\footnotetext{
${ }^{5}$ www.kompas.com

${ }^{6}$ Bagir Manan, Membedah UUD 1945, UB Press, Malang, 2012, h. 79-80.

7 Jimly Asshiddiqie, Format Kelembagaan Negara dan Pergeseran Kekuasaan dalam UUD 1945, FH UII Press, Yogyakarta, 2005, h.45.
} 
undang-undang yang berkaitan dengan pajak, pendidikan, dan agama. (Pasal 22D ayat (2))

c. Dapat melakukan pengawasan atas pelaksanaan undang-undang mengenai: otonomi daerah, pembentukan, pemekaran, dan penggabungan daerah, hubungan pusat dan daerah, pengelolaan sumber daya alam dan sumber daya ekonomi lainnya, pelaksanaan anggaran pendapatan dan belanja negara, pajak, pendidikan, dan agama serta menyampaikan hasil pengawasannya kepada DPR RI sebagai bahan pertimbangan untuk ditindaklanjuti. (Pasal 22D ayat (3))

d. Memberikan pertimbangan terhadap rancangan undang-undang anggaran pendapatan dan belanja negara yang diajukan oleh Presiden untuk dibahas bersama DPR RI. (Pasal 23 ayat (2))

e. $\quad$ Menerima hasil pemeriksaan keuangan negara. (Pasal 23E ayat (2))

f. Memberikan pertimbangan kepada DPR RI terhadap pemilihan anggota BPK. (Pasal 23F ayat (1)).

Dalam dinamika ketatanegaraan di Indonesia, DPD RI merupakan satu lembaga Negara di Indonesia yang seyogyanya dapat mengambil peran yang strategis dan optimal dalam perwujudan kesinambungan fungsi kelembagaan. Namun realita yang ada, DPD RI sebagai representasi masyarakat di daerah hingga saat ini belum mampu berperan secara dinamis, bahkan kewenangan dan fungsi yang tersemat pada DPD RI tak ubahnya seuah formalitas yang tidak berarah. Hal tersebut dapat dilihat dari kondisi DPD RI secara kelembagaan itu sendiri, baik secara normatif yang termaktub dalam UUD NRI Tahun 1945 maupun secara etikat baik para elit untuk menuntaskan permasalahan ini. MPR RI yang menetapkan perubahan UUD 1945 nyatanya tidak menginginkan DPD RI memiliki kewenangan yang setara dengan DPR, melainkan sebagai badan komplementer DPR RI.

Kewenangan terhadap proses legislasi oleh DPD RI walaupun telah dikuatkan pasca Putusan Mahkamah Konstitusi Nomor 92/PUU-X/2012 dan Putusan Mahkamah Konstitusi Nomor 79/PUU-XII/2014 akan tetapi tidak senyata-nyatanya menjadikan DPD RI menjadi lembaga yang kuat dalam parlemen. Kedudukan DPD RI di bidang legislasi nampak telah setara dengan DPR RI dan Presiden, DPD RI berhak dan/atau berwenang: (i) terlibat dalam penyusunan prolegnas; (ii) dapat mengajukan rancangan undang-undang tertentu (yang berkaitan dengan otonomi daerah, hubungan pusat dan daerah, pembentukan dan pemekaran serta penggabungan daerah, pengelolaan sumber daya alam dan sumber daya ekonomi lainnya, serta yang berkaitan dengan perimbangan keuangan pusat dan daerah); (iii) ikut membahas rancangan undang-undang tertentu tersebut sejak awal dan akhir tahapan, namun DPD RI tidak memberi persetujuan atau pengesahan rancangan undang-undang menjadi undang-undang.

Pelaksanaan pengawasan terhadap Undang-undang tersebut di satu sisi dapat dianalisa merupakan sebuah unsur pelemah kewenangan kelembagaan DPD RI itu sendiri. Dalam perspektif pengaturan dalam konstitusi sendiri, apabila ditelaah mengandung aturan yang bersifat imperatif (tidak mewajibkan). Redaksi "dapat" yang melekat pada kewenangan yang termaktub dalam rumusan pasal 22D tersebut terkesan mengambang. Belum lagi ketika permasalahan tersebut dikaitkan dengan alur mekanisme ketika proses pengawasan tersebut telah dijalankan oleh DPD RI.

Alur mekanisme hasil pengawasan yang telah dilakukan oleh DPD RI tersebut, dalam konstitusi dilanjutkan dengan DPD RI menyampaikan hasil tersebut kepada DPR RI. Alur tersebut kembali seakan melemahkan posisi DPD RI, ketika dalam lanjutan pasal 22D tersebut dijelaskan bahwa hasil pengawasan nantinya dijadikan bahan pertimbangan DPR RI untuk ditindak lanjuti. Proses menindaklanjuti hasil pengawasan ini lah yang sarat menimbulkan permasalahan, bagaimana peran DPD RI sangat lemah dalam alur pelaksanaan proses pengawasan tersebut. 
Dalam tata tertib DPR RI mengenai aturan alur progress proses pengawasan Undangundang, diatur bahwa ketika hasil pengawasan tersebut telah diberikan oleh DPD RI kepada DPR RI, hasil tersebut dapat dijadikan sebagai bahan pertimbangan dan masukan bagi DPR RI dan dapat ditindaklanjuti, tanpa diatur mengenai kewajiban apa mengenai proses penindaklanjutan hasil pengawasan yang telah dilakukan oleh DPD RI. Ironisnya, DPR RI tidak dipersalahkan, dalam arti tidak ada konsekuensi hukum ketika DPR RI tidak menindaklanjuti hasil pengawasan terhadap Undang-undang yang diberikan oleh DPD RI. Dalam tata tertib DPR RI hanya diatur, ketika DPR RI tidak menindaklanjuti hasil tersebut, DPD RI dapat meminta penjelasan kepada pimpinan DPR RI, dan DPD RI mendapatkan penjelasan secara tertulis dari DPR RI. ${ }^{8}$

Berbagai permasalahan kompleks tersebut secara logis mengarahkan kepada kiprah DPD RI dalam sistem ketatanegaraan Indonesia. Keoptimalan dilembagakannya DPD RI sebagai penjelmaan representasi kepentingan daerah masih perlu dikaji lebih dalam, dengan memperhatikan faktor terkait baik dalam politik pembentukannya hingga pengaturan dalam konstitusi yang dirasa kian memberatkan posisi DPD RI itu sendiri. Perlu kiranya dikaji ulang mengenai eksistensi keberadaan lembaga DPD RI. Tentu saja hal tersebut juga patut didasari oleh sebuah penegasan arah kelembagaan khususnya sistem parlemen yang akan dianut oleh Indonesia.

Perkembangan pengertian parlemen saat ini nampaknya tidak hanya berbicara tentang fungsi legislasi yang diselenggarakan oleh kekuasaan legislatif. Pada hakikatnya fungsi legislasi yang dimiliki oleh parlemen merupakan fungsi yang tidak lebih besar dibandingkan dengan fungsi control (controlling). Historis terbentuknya lembaga parlemen dalam sejarah Eropa dilatar belakangi oleh kebutuhan untuk mengawasi dan mengendalikan pelaksanaan tugas-tugas pemerintah. Istilah parlemen berasal dari bahasa Perancis yaitu parle yang berarti to speak (berbicara) hal ini akan sepadan jika kemudian dimaknai dengan fungsi kontrol. ${ }^{9}$ Adanya fungsi kontrol yang dimiliki oleh parlemen tidak lain sebagai pengejawantahan pemisahan kekuasaan yang kemudian melahirkan prinsip checks and balances. Prinsip checks and balances itu sendiri bertujuan saling mengawasi agar masing-masing cabang kekuasaan yang terpisah tidak sewenang-wenang dan sebagai cara meningkatkan kualitas putusan.

Pemisahan kekuasaan dewasa ini sebenarnya tidak hanya dimaknai laiknya apa yang dikemukakan oleh Montesqieu dengan Trias Politica-nya. Pandangan Montesqieu dalam pemisahan kekuasaan justru tidak mencerminkan adanya checks and balances. Dalam ajaran Trias Politica hakim dianggap a-politis, akan tetapi Montesqieu khawatir terhadap kemungkinan penyalahgunaan kebebasan hakim. Hal ini dapat dipahami karena pada masa itu hakim sebelum dan sesudah Revolusi Perancis merupakan hasil pengangkatan dan pilihan raja. Oleh karenanya menurut Montesqieu lembaga yudisial hanya dibatasi sebagai bouche de lal loi (mulut undang-undang) yitu hanya menerapkan apa yang telah tertulis didalam UndangUndang saja. ${ }^{10}$ Lembaga yudisial secara praktis dijadikan sebagai perpanjangan lembaga eksekutif, pada awal Revolusi Perancis, para hakim dilarang untuk melakukan interpretasi terhadap undang-undang, apabila terjadi keraguan terhadap ketentuan suatu undang-undang maka para hakim harus pergi bertanya kepada pembentuk undang-undang. ${ }^{11}$

\footnotetext{
${ }^{8}$ Sirajudin dkk. Membangun Konstituen Meeting: Memperkuat Kepentingan Daerah dengan Keterbatasan Wewenang DPD. Malang: MCW. 2006

${ }^{9}$ Erfandi, Parliamentary Threshold dan HAM dalam Hukum Tata Negara Indonesia, Setara Press, Malang, 2014, h. 123.

${ }^{10}$ A.S.S. Tambunan, Dualisme Naskah UUD 1945, Pustaka Sinar Harapan, Jakarta, 1993, h. 49.

11 Ibid.
} 
Dewan Perwakilan Daerah Republik Indonesia (DPD RI) kedepan memiliki wacana akan dikuatkan posisinya dalam parlemen (Lembaga Legislatif) Indonesia sebagai wujud adanya check and balances di dalam parlemen yang berbentuk sistema bikameral. Parlemen sendiri dalam sebuah pengertian secara laterlijk berasal dari bahasa latin parliamentum atau dalam bahasa Perancis parler yang berarti berbicara, dan dapat diartikan suatu tempat atau badan di mana para wakil rakyat berbicara satu sama lain untuk membicarakan hal-hal penting yang berkaitan dengan kepentingan rakyat. ${ }^{12}$ Secara umum ada tiga prinsip perwakilan yang dikenal di dunia. Pertama, representasi politik (political representation), yaitu perwakilan melalui prosedur partai politik sebagai salah satu pilar demokrasi modern. Kedua, representasi territorial (territorial representation) yang merupakan perwakilan daerah. Dan ketiga, representasi fungsional (functional representation) yaitu mencerminkan keterwakilan fungsional, misalkan di Inggris adalah kelompok-kelompok tuan tanah dan para Bangsawan Inggris yang dulunya berkuasa mutlak, yang selanjutnya ditampung kepentingannya dalam wadah House of Lord. ${ }^{13}$ Dibanyak negara modern terhadap sistem perwakilan yang telah disebutkan tersebut, lebih banyak menganut double check karena dianggap lebih ideal, yakni tidak hanya political representation saja melainkan juga territorial representation ataupun functional representation. Kerena itu, banyak diantaranya mengadopsi keduanya dengan membentuk struktur parlemen bikameral atau dua kamar.

Sistem parlemen bikameral adalah sistema parlemen yang terdiri dari dua kamar atau badan. Kamar pertama biasa disebut dengan Majelis Rendah (lower house) atau DPR atau House of Commons atau House of Representatives, sedangkan kamar kedua disebut Majelis Tinggi atau Senat atau House Of Lords. Hanya di Belanda menamai majelis tingginya dengan kamar pertama dan majelis rendahnya dengan kamar kedua.

Menurut Strong, secara umum terdapat beberapa karakter dari sistema parlemen bikameral, yaitu: ${ }^{14}$

1. Kamar kedua cenderung lebih kecil daripada kamar pertama.

2. Masa jabatan anggota kamar kedua lebih lama dibanding masa jabatan anggota kamar pertama.

3. Anggota kamar pertama dipilih secara bertahap atau bersama.

menurut Peter Lalienfeld, ciri-ciri lebih spesifik tentang kamar kedua adalah sebagai berikut: ${ }^{15}$

1. Representating regions at the central level

2. Affording representation to interest/ classes that may not get a voice in the first chamber

3. Composed in a different way to the first chamber. Mambers may be appointed regionally, indirectly, or by some different mechanism to that of the fist chamber.

4. As such, acting as a moderator to the first chamber. This is often siginificant where the fist chamber is dominated by the majority party.

5. Capable of voting, or at least delaying, some or all types of legislation.

6. Capable of initiating legislation whitin its field of relevance (eg regional matters)

7. Its consent required for siginificant political/ constitutional decisions.

\footnotetext{
12 Muchammad Ali Safa'at, Parlemen Bikameral: Studi Perbandingan di Amerika Serikat, Perancis, Belanda, Inggris, Austria, dan Indonesia, UB Press, Malang, 2010, h. 24.

13 JImly Asshiddiqie, Pokok-Pokok Hukum Tata Negara Indonesia Pasca Reformasi, PT. Bhuana Ilmu Populer, Jakarta, 2007, h. 154.

${ }^{14}$ Mucammad Ali Safa'at, Op.Cit. h.35.

15 Ibid.
} 


\section{Kendala yang Dihadapi Dewan Perwakilan Daerah dalam Menjalankan Tugas dan Fungsinya}

Dewan Perwakilan Daerah Republik Indonesia (DPD RI) dalam menjalankan tugas dan fungsinya sering kali tidak maksimal dikarenakan adanya kendala-kendala yang dihadapi. Dalam hal ini kendala yang sering ditemukan dapat dibagi menjadi dua macam, yaitu kendala internal yang berarti dari dalam DPD RI sendiri, dan kendala eksternal yang berasal dari luar DPD RI.

\section{a. Kendala Internal yang Dihadapi Dewan Perwakilan Daerah dalam Menjalankan Tugas dan Fungsinya.}

Kendala Internal yang ditemukan dalam DPD RI dalam menajalankan tugas dan fungsinya pertama adalah Sumber Data Manusia. Sebagaimana disampaikan oleh Deni Martanti, S. Kom. Staf Ahli DPD RI Provinsi Kalimantan Tengah dinyatakan bahwa "Anggota DPD RI dipilih berdasarkan suara terbanyak yang memiliki daerahnya. Dimana setiap Anggota DPD RI terdiri dari berbagai latar belakang pendidikan, budaya, agama dari daerah yang berbeda. Anggota DPD RI kebanyakan merupakan tokoh daerah, atau putra daerah."

Latar belakang dari setiap anggota DPD RI ini menjadi salah satu kendala yang dimiliki oleh anggota DPD RI dalam menjalankan tugas dan fungsinya. Jika Anggota DPD RI yang terpilih tidak memiliki latar belakang pendidikan tinggi atau menguasai ilmu terkait kenegaraan dan perekonomian atau yang telah berpengalaman dalam pemerintahan akan susah membuat kebijakan ataupun keputusan ataupun sikap anggota DPD tersebut dalam Sidang Paripurna.

Selain latar belakang Anggota DPD RI, pengetahuan Anggota DPD RI tentang tugas dan fungsi nya terkadang belum diketahui, hal ini seperti disampaikan oleh Oni Suwarman, yang sukses menjadi calon anggota DPD RI asal Jawa Barat ini, mengatakan belum tahu apaapa menyangkut soal tugas dan fungsi yang dimiliki oleh DPD RI. Beliau menyatakan "Terus terang saya belum tahu persis kerjanya anggota DPD itu apa saja, lalu masuk kerjanya mulai dari jam 07.00 sampai jam berapa," pada saat diwawancarai oleh Media Tempo pada Kamis, 5 Juni $2014 .^{16}$

Pemerhati Hukum Tata Negara, Refli Harun mengatakan bahwa "Secara individual DPD harus meningkatkan kinerjanya dengan meningkatkan performancenya secara individu. Seperti dilakukan Fahira Idris. Sebab, " lebih lanjut beliau mengatakan bahwa "dengan demikian, peran DPD RI lebih kepada individual. yaitu, harus mampu merespon berbagai peristiwa yang ada khususnya di daerah seperti kasus freeport, pertambangan, dan lain-lain terkait kekayaan alam di daerah, sehingga bisa menjadi news maker (pembuat berita). 'Jangan menjadi anggota DPD RI yang justru menikmati kewenangan yang ada, atau DPD RI dijadikan tempat istirahat karena sudah capek di DPR RI” Tegas Refli Harun dalam Dialog Kenegaraan 'Revitalisasi DPD RI'. ${ }^{17}$

Kendala Internal yang Kedua bagi Anggota DPD RI dalam menjalankan tugas dan fungsinya adalah kantor yang cukup representatif, dalam hal mudah dijangkau masyarakat, tidak memerlukan biaya tinggi. Karena pada dasarnya DPD RI adalah perwakilan daerah maka sudah seharusnya memberikan pelayanan kepada masyarakat di daerah, menampung aspirasi mereka dan memperjuangkannya di Sidang Paripurna. Kemudian apabila kantor DPD RI susah dijangkau masyarakat, bagaimana masyarakat dapat memberikan aspirasinya apabila kantornya susah untuk dikunjungi.

\footnotetext{
${ }^{16}$ https://m.tempo.co/read/news/2014/06/06/058582876/pelawak-oni-masih-kebingungan-soaltugas-jadi-dpd diakses pada tanggal 2 Desember 2016.
}

${ }^{17}$ http://www.pikiran-rakyat.com/politik/2016/03/03/363121/penguatan-kinerja-dpd-bisa-lewat-institusidan-personal diakses pada tanggal 2 Desember 2016. 
Kemudian infrastuktur lainnya adalah terkait sarana kominikasi elektronik yang dapat diandalkan (telepon, fax, dan website atau sistem informasi dan teknologi) saat ini masih kurang memadai dalam hal tidak langsung memberikan fast respon terhadap masyarakat.

\section{b. Kendala Ekternal yang Dihadapi Dewan Perwakilan Daerah dalam Menjalankan Tugas dan Fungsinya.}

Kendala lain yang dihadapi oleh DPD RI selain dari dalam lembaganya sendiri juga menemui kendala dari faktor eksternal. Pertama adalah pemahaman terhadap tugas dan fungsi DPD RI oleh masyarakat. Masyarakat masih banyak yang tidak mengetahui untuk apa DPD RI tersebut, yang diketahui hanyalah bahwa tempat menyalurkan aspirasi hanya dimiliki oleh Dewan Perwakilan Rakyat saja. Ketidakpahaman masyarakat terhadap tugas dan fungsi DPD RI sebenarnya beralasan, karena DPD RI selama ini tidak mampu memaksimalkan kinerjanya. DPD RI yang seharusnya menjadi "corong" bagi daerah nyatanya tidak mampi dimaksdimalkan. Hal ini juga sebagaimana dikatakan oleh Yunarto, "Saya melihat, DPD belum maksimal memainkan isu. Jarang didengar adanya suara yang tegas dan cerdas dari anggota DPD untuk menyikapi persoalan yang sedang berkembang. Tidak hanya di media nasional, pendapat anggota DPD juga sulit ditemui di media lokal tempat asal mereka. Padahal, anggota DPD seharusnya dapat menjadi penekan pimpinan di daerahnya agar bekerja dengan lebih baik."18

Ketidaktahuan masyarakat akan DPD RI tentunya tidak akan menyukseskan langkah DPD RI untuk memperjuangkan kesetaraan kewenangan dalam parlemen sehingga mampu terbentuk strong bicameral dalam parlemen, karena kinerja yang tidak maksimal justru muncul wacana untuk pembubaran DPD RI. Mantan Kepala Pusat Pengkajian Kemajelisan MPR, Janedjri M Gaffar menyatakan bahwa " Jika kinerja DPD RI sudah dirasakan manfaatnya oleh masyarakat di daerah, tentunya masyarakat di daerah akan membela DPD RI. Akan tetapi, jika masyarakat di daerah apatis dan tidak menunjukkan kepeduliannya kepada DPD RI, maka anggota DPD harus melakukan koreksi ke dalam, apakah kinerjanya selama ini sudah memberikan manfaat untuk masyarakat. DPD RI harus menunjukkan dan membuktikan kinerjanya benar-benar memperjuangkan aspirasi masyarakat di daerah. DPD RI harus bersama-sama memperjuangkan aspirasi masyarakat daerah,"19

Kendala ekternal yang kedua adalah keterbatasan kewenangan yang dimiliki oleh DPD RI dalam parlemen Indonesia. Pasca reformasi lembaga-lembaga negara dikehendaki tidak memiliki kekuasaan yang absolut untuk menghindari adanya praktek korupsi, kolusi, dan nepotisme begitu juga terhadap diri parlemen. Parlemen di Indonesia kemudian dirubah memiliki sistem dua kamar (bikameral), tetapi cenderung memilih kepada yang soft bicameral. Oleh pembuat UUD NRI 1945 kewenangan DPD RI dalam legislasi misalnya hanya terbatas pada pengusulan, dan pembahasan saja, itupun hanya pada rancangan undang-undang yang berkaitan dengan otonomi daerah.DPD RI tidak memiliki kewenagan lain yang berupa ikut memutus rancangan undang-undang. Hal tersebut yang membuat kesan bahwa hadirnya DPD RI hanyalah sebagai pemanis untuk dianutnya prinsip check and balances dalam parlemen, yang pada nyatanya kekuasaan DPR RI lebih besar dari DPD RI. Sejatinya membandingkan kinerja DPR RI dan DPD RI tidaklah tepat karena ratio legis lahirnya kedua lembaga negara ini berbeda. Refly Harun mengatakan bahwa "bagaimana pun sulit jika harus dibandingkan

${ }^{18} \mathrm{http}: / /$ www.polmarkindonesia.com/index2.php?option=com content $\&$ do $\mathrm{pdf}=1 \& \mathrm{id}=4307$

Diakses pada tanggal 2 Desember 2016

${ }^{19}$ http://www.hukumonline.com/berita/baca/lt56d6bcc965e1d/ini-pesan-praktisi-hukum-tata-negarauntuk-dpd diakses pada tanggal 2 Desember 2016 
dengan DPR RI. "DPR RI bagaimana pun dalam pembahasan APBN, rakyat tetap menunggu putusan DPR RI. Bukan DPD RI. Meski banyak korupsi, putusan DPR RI tetap ditunggu, ,20

\section{Upaya Yang Dilakukan Untuk Peningkatan Kemampuan Dewan Perwakilan Daerah Dalam Menjalankan Tugas Dan Fungsinya}

\section{a. Institusionalisasi Politik}

Perubahan ketatanegaraan di Indonesia terjadi melalui tahapan transisi dan konsolidasi demokrasi. ${ }^{21}$ Transisi demokrasi adalah titik awal peralihan dari rezim otoritarian dengan rezim demokratis. Transisi dimulai dari keruntuhan rezim otoritarian lama, yang kemudian diikuti atau berakhir dengan pengesahan lembaga-lembaga politik dan aturan politik baru di bawah payung demokrasi.

Konsolidasi demokrasi mencakup peningkatan secara prinsipil komitmen seluruh elemen masyarakat pada aturan main demokrasi. ${ }^{22}$ Konsolidasi demokrasi juga dipahami sebagai sebuah proses panjang yang mengurangi kemungkinan pembalikan demokratisasi, mencegah erosi demokrasi, menghindari keruntuhan demokrasi, yang diteruskan dengan melengkapi demokrasi, pendalaman demokrasi dan mengorganisir demokrasi secara berkelanjutan. ${ }^{23}$

Dalam konsolidasi demokrasi diawali dengan negosiasi (transaksi) politik yang hendak mempromosikan sistem atau aturan main baru ketimbang merusak sistem lama. Struktur dan prosedur politik yang berlangsung selama proses transisi akan dimantapkan, diinternalisasikan dan bahkan diabsahkan dalam proses konsolidasi. Akhirnya proses konsolidasi akan menghasilkan penetapan sistem demokrasi secara operasional dan ia akan memperoleh kredibilitas di hadapan masyarakat. Karena itu, konsolidasi demokrasi tidak hanya merupakan proses politik yang terjadi pada level prosedural dan lembaga-lembaga politik, tetapi juga pada level masyarakat. Demokrasi yang terkonsolidasi bila aktor-aktor politik, partai, kelompok kepentingan, dan lainnya menganggap bahwa tindakan demokratis sebagai alternatif utama untuk meraih kekuasaan (democracy as the only game in town), dan tidak ada aktor atau kelompok yang mempunyai klaim terhadap tindakan yang sudah dipilih secara demokratis.

Proses konsolidasi demokrasi jauh lebih kompleks dan panjang setelah transisi. Karena itu, studi-studi tentang konsolidasi demokrasi juga jauh lebih kompleks dan bervariasi ketimbang studi transisi. Salah satu fokus pendekatan studi konsolidasi demokrasi, menurut Larry Diamond adalah pendekatan institusional. ${ }^{24}$

Pendekatan institusional, menurut Larry Diamond, yaitu pentingnya institusionalisasi politik dalam proses konsolidasi demokrasi. Pendekatan ini merupakan bagian dari tiga tugas dalam konsolidasi demokrasi: pendalaman demokrasi, institusionalisasi politik dan mengontrol

\footnotetext{
${ }^{20}$ http://www.pikiran-rakyat.com/politik/2016/03/03/363121/penguatan-kinerja-dpd-bisa-lewat-institusidan-personal diakses pada tanggal 2 Desember 2016.

${ }^{21}$ Samuel P. Huntington, 1995, Gelombang Demokratisasi Ketiga, (Jakarta: Grafiti). Alfred Stepan, 1993, "Berbagai Jalur Menuju Demokratisasi: Sejumlah Pertimbangan Teoritis dan Komparatif", dalam Guillermo O’Donnell, Philippe C. Schmitter and Laurence Whitehead (eds.), 1993, Transisi Menuju Demokrasi : Tinjauan Berbagai Perspektif, (Jakarta: LP3ES), hlm. 104-143. Giuseppe di Palma, 1997, Kiat Membangun Demokrasi: Sebuah Esai tentang Transisi Demokrasi, (Jakarta: Yayasan Sumber Agung).

22 Laurence Whitehead, 1989, "The Consolidation of Fragile Democracy", dalam Robert Pastor (ed.), Democracy in the Americas, (New York: Holmes), hlm.30.

${ }^{23}$ Andreas Schedler, 1998, "What is Democratic Consolidation?", Journal of Democracy, No. 2.

${ }^{24}$ Larry Diamond, 2003, Developing Democracy Toward Consolidation, (Yogyakarta: IRE).
} 
kinerja rezim. Pendalaman demokrasi membuat struktur-struktur formal demokrasi menjadi lebih liberal, akuntabel, representatif dan aksesibel. ${ }^{25}$

Institusionalisasi politik melibatkan konvergensi yang mapan pada tingkat aturan dan prosedur dalam persaingan dan aksi politik. ${ }^{26}$ Konsolidasi demokrasi harus mampu melakukan penguatan tiga tipe institusi politik, yaitu aparat administrasi negara (birokrasi); institusi representasi; penyelenggaraan demokrasi (partai politik, parlemen dan sistem pemilihan umum); struktur-struktur yang menjamin akuntabilitas horisontal, konstitusionalisme, dan pemerintahan berdasar hukum (sistem peradilan dan lembaga pengawasan). Institusionalisasi politik ini adalah upaya memperkuat struktur demokrasi representatif dan pemerintahan formal, sehingga menjadi lebih koheren, kompleks, otonom, mudah beradaptasi, dan karenanya lebih kapabel, efektif, berharga, dan mengikat.

Institusionalisasi politik melibatkan konvergensi yang mapan pada tingkat aturan dan prosedur dalam persaingan dan aksi politik. ${ }^{27}$ Konsolidasi demokrasi harus mampu melakukan penguatan tiga tipe institusi politik, yaitu aparat administrasi negara (birokrasi); institusi representasi; penyelenggaraan demokrasi (partai politik, parlemen dan sistem pemilihan umum); struktur-struktur yang menjamin akuntabilitas horisontal, konstitusionalisme, dan pemerintahan berdasar hukum (sistem peradilan dan lembaga pengawasan). Institusionalisasi politik ini adalah upaya memperkuat struktur demokrasi representatif dan pemerintahan formal, sehingga menjadi lebih koheren, kompleks, otonom, mudah beradaptasi, dan karenanya lebih kapabel, efektif, berharga, dan mengikat.

Proses konvergensi elite dalam konsolidasi demokrasi tidak sekedar untuk mencapai kesepakatan atau untuk mengakhiri konflik di antara mereka, tetapi juga menjadi bagian dari proses institusionalisasi politik, yang di dalamnya mencakup agenda rekonstitusi maupun penciptaan prosedur kelembagaan baru yang kondusif bagi demokrasi. Institusionalisasi politik pada dasarnya hendak melakukan reformasi sistemik institusi politik, prosedur dan aturan main yang lebih cocok dengan demokrasi.

Setidaknya ada tiga sasaran dalam melakukan institusionalisasi politik, yaitu (1) institusi eksekutif-negara (lembaga kepresidenan, sistem pemerintahan, birokrasi dan militer); (2) institusi perwakilan (parlemen, partai politik dan pemilihan umum); dan (3) lembaga peradilan dan sistem hukum. Dalam konteks ini, para pemimpin politik melakukan crafting yang didukung oleh partisipasi dan konsultasi publik, untuk membuat sistem baru yang dituangkan dalam konstitusi atau perundang-undangan. Tujuan institusionalisasi politik ini adalah membuat institusi politik menjadi lebih akuntabel, transparan, terkontrol, responsif, partisipatif, dan berpijak pada rule of law.

Urgensi rekonstitusi (perubahan konstitusi) dalam konsolidasi demokrasi adalah bahwa norma-norma konstitusional baru yang dihasilkan dari konsolidasi konstitusional, hadir pada langkah awal dalam proses konsolidasi demokrasi ${ }^{28}$ Norma-norma itu memberi petunjuk polapola perilaku formal dalam konstestasi politik, yang dikembangkan dan dinegosiasikan dalam proses transisi, dan memantapkan standarisasi penyelenggaraan kekuasaan. Kegiatan

25 Adam Przeworski et.al. (eds.), 1999, Democracy, Accountability and Representation, (Cambridge: Cambridge University Press).

${ }^{26}$ John Higley and Richard Gunther (eds.), 1992, Elites and Democratic Consolidation in Latin America and Southern Europe, (Cambridge: Cambridge University Press).

27 John Higley and Richard Gunther (eds.), 1992, Elites and Democratic Consolidation in Latin America and Southern Europe, (Cambridge: Cambridge University Press).

${ }^{28}$ Felipe Aguero, 1995, Soldiers, Civilians, and Democracy: Post-Franco Spain in Comparative Perspective, (Baltimore: The John Hopkins University Press). 
merancang konstitusi baru (rekonstitusi atau perubahan konstitusi) terjadi pada bagian awal konsolidasi demokrasi, dan mulai memberi kesempatan pada konsolidasi level berikutnya. Bahkan konstitusi baru yang telah terbentuk akan memberikan jaminan bagi prosedur tetap pembuatan keputusan politik. Pada akhirnya, implementasi dari konstitusi baru merupakan dasar bagi format baru sistem politik dan institusi politik.

Perubahan UUD 1945 diarahkan kepada tersedianya konstitusi yang demokratis, yaitu konstitusi yang memberikan jaminan kepastian hukum dalam pengaturan lembaga negara dan kewenangannya, jaminan kepastian perlindungan terhadap hak asasi warga negara, dan jaminan tersedianya mekanisme checks and balances dalam penyelenggaraan pemerintahan negara. Dengan demikian, agenda perubahan konstitusi UUD 1945 dapat diartikan sebagai agenda menyusun ulang desain negara (redesigning the state). ${ }^{29}$ Karena perubahan konstitusi sebagai agenda mendesain ulang negara, maka perubahan konstitusi UUD 1945 diarahkan kepada perumusan ulang gagasan kedaulatan rakyat, bagaimana implementasi gagasan kedaulatan rakyat dalam praktek ketatanegaraan, dan diikuti dengan pembentukan lembaga negara dan pemberian kewenangan kepadanya dalam rangka pelembagaan negara. ${ }^{30}$

Dalam konteks konsolidasi demokrasi ini nampaknya tidak selalu terarah. Salah satunya adalah tidak tuntasnya design ketatanegaraan Indonesia. Dalam arti institusionalisasi politik, munculnya begitu banyak lembaga-lembaga Negara baru belum menunjukkan pembentukannya by design, namun lebih berkarakter dadakan sebagai akibat pilihan kebijakan politik tertentu. Sebagai konsekuensi penataan ketatanegaraan "miskin design" itu adalah kecenderungan lahirnya "komisi negara independen" (independent regulatory agencies) maupun lembaga negara non struktural lainnya, seperti komisi eksekutif (executive branch agencies), atau lembaga penunjang negara (auxillary bodies) melonjak drastis. ${ }^{31}$

Tentu saja dalam konteks konsolidasi demokrasi, terutama konsolidasi lembaga negara, dapat dikatakan tidak berjalan efektif. Justru kini memunculkan sejumlah penilaian bahwa agenda demokratisasi memakan banyak biaya karena kegagalan dalam melakukan konsolidasi lembaga negara. Oleh karena itu, untuk menjamin tujuan awal agenda konsolidasi demokrasi, yaitu pelembagaan politik secara efektif yang menjamin proses ketatanegaraan berjalan efektif, menjamin pelayanan warga negara, terciptanya checks and balances, dan menghindari konflik antar lembaga negara, maka sudah saatnya diperlukan agenda penataan lembaga Negara.

b. Kewenangan Dewan Perwakilan Daerah

Sejak awal kehadirannya, Dewan Perwakilan Daerah (DPD) yang lahir melalui perubahan UUD 1945 (amandemen ketiga) telah memunculkan dilema tersendiri.

${ }^{29}$ Daniel J. Elazar, 1985, “Constitution-making: The Pre-eminently Political Act”, dalam Keith G. Banting, and Richard Simeon, (eds.), 1985, The Politics of Constitutional Change in Industrial Nations: Redesigning The State, (London: The MacMillan Press Ltd.), hlm. 232-248.

${ }^{30}$ John P. Wheeler Jr. menyatakan bahwa "The major of a constitution is threefold: (1) to protect the people in the exercise of their civil liberties; (2) to define the powers of government; (3) to establish the more important, the more permanent institutions of government, such as the executive, the legislative and the judicial." Lihat: John P. Wheeler Jr., (ed.), 1961, Salient Issues of Constitutional Revision, (New York: National Municipal League), hlm. xii.

${ }^{31}$ Denny Indrayana, 2007, "Komisi Negara Independen: Evaluasi Kekinian dan Tantangan Masa Depan", makalah disampaikan pada "Dialog Nasional Hukum dan Non Hukum: Penataan State Auxillary Bodies Dalam Sistem Ketatanegaraan", diselenggarakan oleh Departemen Hukum dan HAM, Badan Pembinaan Hukum Nasional kerja sama dengan Fakultas Hukum, Universitas Airlangga, Surabaya, 26-29 Juni 2007, hlm. 1. 
Secara kelembagaan, DPD merupakan sebuah parlemen atau lembaga legislatif, bahkan MPR sebagai pembentuk UUD 1945 menegaskan bahwa DPD diadakan untuk tiga (3) alasan mendasar mengakomodasi keberadaan DPD dalam struktur ketatanegaraan Indonesia, yaitu: ${ }^{32}$

(1) Memperkuat ikatan daerah-daerah dalam wadah Negara Kesatuan Republik Indonesia;

(2) Meningkatkan agregasi dan akomodasi aspirasi dan kepentingan daerah-daerah dalam perumusan kebijakan nasional berkaitan dengan Negara dan daerah-daerah;

(3) Mendorong percepatan demokrasi pembangunan dan kemajuan daerah secara serasi dan seimbang

Apabila dicermati isi dari Pasal 22 UUD 1945, maka terdapat kewenangan yang tidak signifikan, yaitu:

(1) Dapat mengajukan ke DPR RUU yang terkait dengan otonomi daerah, hubungan pusat dan daerah, pembentukan dan pemekaran serta penggabungan, serta penggabungan daerah, pengelolaan sumber daya alam dan sumber daya ekonomi dan perimbangan keuangan pusat dan daerah;

(2) Ikut membahas RUU yang terkait dengan otonomi daerah, hubungan pusat dan daerah, pembentukan dan pemekaran serta penggabungan daerah,pengelolaan sumber daya alam dan sumber daya ekonomi lainnya dan perimbangan keuangan pusat dan daerah;

(3) Memberi pertimbangan kepada DPR atas RUU APBN dan RUU yang terkait dengan pajak, pendidikan dan agama;

(4) Melakukan pengawasan dan pelaksanaan UU yang terkait otonomi daerah, hubungan pusat dan daerah, pembentukan dan pemekaran serta penggabungan daerah, hubungan pusat dan daerah, pengelolaan sumber daya alam dan sumber daya ekonomi lainnya dan perimbangan keuangan pusat dan daerah serta menyampaikan hasil pengawasan kepada DPR;

(5) Menerima hasil pemeriksaan keuangan dari BPK;

(6) Memberikan pertimbangan kepada DPR mengenai pemilihan anggota BPK.

Dengan adanya kewenangan sebagaimana diatur dalam Pasal 22 D ayat (1) dan (2), Pasal 23 E ayat (2), Pasal 23 F ayat (1) UUD 1945, dapat dikemukakan bahwa DPD tidak lebih dari sekedar aksesoris DPR. ${ }^{33}$

Terkait dengan kewenangan DPD sebagaimana dipaparkan dalam uraian di atas, pengaturan kewenangan DPD di dalam UUD 1945 sebagai konstitusi dasar tertulis di Indonesia menegaskan bahwa pengaturan DPD dalam UUD 1945 sebagai alat perlengkapan Negara ((lembaga Negara = permanent institutions) yang dilengkapi dengan fungsi dan hak-haknya, dinyatakan oleh James Bryce termasuk dalam kekuasaan pemerintahan. ${ }^{34}$

Seiring dengan lahirnya DPD sebagai salah satu lembaga Negara yang keberadaannya diatur dalam UUD 1945, keberadaan DPD memunculkan kritik.

Kritik yang pertama terkait dengan kewenangan yang dimiliki oleh DPD. Kewenangan DPD dipandang tidak cukup signifikan dilihat dari gagasan pembentukannya dan DPD memang didesain lebih rendah dari DPR. ${ }^{35}$

32 Sirajuddin \& Winardi, Dasar-dasar Hukum Tata Negara Indonesia, Setara Press, Malang, 2015, halaman 118-119.

33 Ibid.

${ }^{34}$ Sri Soemantri, Bunga Rampai Hukum Tata Negara Indonesia, Alumni, Bandung, 1992.

${ }^{35}$ Sirajuddin dan Winardi, Op. Cit., halaman 87. 
Krtitik kedua terkait dengan rumusan dalam Pasal 7C UUD 1945 hanya memberikan jaminan bahwa hanya DPR yang tidak bisa dibubarkan oleh Presiden sehingga DPD dapat dibubarkan oleh Presiden, karena tidak ada jaminan yang tegas dan eksplisit dalam UUD 1945; dan ketentuan dalam Pasal 11 ayat (1) dan (2) UUD 1945 menyebutkan bahwa hanya pertimbangan DPR yang diperlukan oleh Presiden ketika menyatakan perang, damai dan dalam membuat perjanjian internasional. ${ }^{36}$

Kewenangan yang dimiliki oleh DPD memperlihatkan betapa terbatasnya kewenangan DPD bilamana dibandingkan dengan DPR. Keterbatasan kewenangan DPD ini sudah disadari oleh anggota DPD semenjak para calon anggota DPD meneguhkan niat mereka mengikuti Pemilu. Keterbatasan kewenangan tersebut baru benar-benar dirasakan DPD pada saat para anggota DPD menjalankan jabatannya sebagai anggota DPD. ${ }^{37}$

c. Bekerjanya Dewan Perwakilan Daerah

Di dalam paparan terdahulu telah dikemukakan kewenangan dari Dewan Perwakilan Derah yang diatur dalam UUD 1945. Selanjutnya, kewenangan tersebut dijabarkan secara rinci di dalam Pasal 249 Undang-undang Nomor 17 Tahun 2014 tentang MPR, DPR, DPD, DPRD yang isinya dinyatakan:

(1) DPD mempunyai wewenang dan tugas:

a. Mengajukan rancangan undang-undang yang berkaitan dengan otonomi daeah, hubungan pusat dan daerah, pembentukan dan pemekaran serta penggabungan daerah, pengelolaan sumber daya alam dan sumber daya ekonomi lainnya, serta yang berkaitan dengan perimbangan keuangan pusat dan daerah kepada DPR;

b. Ikut membahas rancangan undang-undang yang berkaitan dengan hal sebagaimana dalam huruf a;

c. Menyusun dan menyampaikan daftar inventaris masalah rancangan undang-undang yang berasal dari DPR atau Presiden yang berkaitan dengan hal sebagaimana dimaksud dalam huruf a;

d. Memberikan pertimbangan DPR atas rancangan undang-undang tentang APBN dan rancangan undang-undang yang berkaitan dengan pajak,pendidikan, dan agama;

e. Dapat melakukan pengawasan atas pelaksanaan unang-undang mengenai otonomi daerah, pmbentukan, pemekaran, dan penggabungan daerah, hubungan pusat dan daerah, pengelolaan sumber daya alam, dan sumber daya ekonomi lainnya, pelaksanaa APBN , Pajak, pendidikan dam agama;

f. Menyampaikan hasil pengawasan atas pelaksanaan undang-undang mengenai otonomi daerah, pembentukan, pemekaran, dan penggabungan daerah, hubungan pusat dan daerah, pengelolaan sumber daya alam dan sumber daya ekonomi lainnya, pelaksanaan undan-undang APBN, pajak, pendidikan, dan agama kepada DPR sebagai bahan pertimbangan untuk ditindaklanjuti;

g. Menerima hasil pemeriksaan atas keuangan Negara dari BPK sebagai bahan membuat pertimbangan kepada DPR tentang rancangan undng-undang yag berkaitan dengan APBN;

h. Memberikan pertimbangan kepada DPR dalam pemilihan anggota BPK; dan

i. Menyusun program legislasi nasional yang berkaitan dengan otonomi daerah, hubungan pusat dan daerah, pembentukan dan pemekaran serta penggabungan daerah,pengelolaan sumber daya alam dan sumber daya ekonomi lainnya, serta yang berkaitan dengan perimbangan keuangan pusat dan daerah.

36 Ibid.

37 A. Salman Manggalatung, Desain Kelembagaan Negara Pasca Amandemen UUD 1945, Gramata Publishing, Bekasi, 2016, halaman 80. 
(2) Dalam menjalankan tugas pengawasan sebagaimana dimaksud pada ayat (1) huruf d, anggota DPD dapat melakukan rapat dengan pemerintah daerah, DPRD dan unsur masyarakat di daerahnya.

Guna melaksanakan tugas dan wewenangnya tersebut DPD mempunyai alat kelengkapan yang keberadaannya diatur dalam Pasal 259 Undang-undang Nomor 17 Tahun 2014 tentang MPR, DPR, DPD, DPRD yang isinya dinyatakan:

a. Pimpinan;

b. Panitia Musyawarah;

c. Panitia Kerja;

d. Panitia Perancang Undang-undang;

e. Panitia Urusan Rumah Tangga;

f. Badan Kehormatan; dan

g. Alat kelengkapan lain yang diperlukan dan dibentuk oleh rapat paripurna.

Apabila dilihat dari wewenang dan tugasnya, DPD mmiliki tugas yang sangat berat, kondisi ini erat hubungannya dengan pengangkatan anggota DPD yang dilakukan melalui mekanisme pemilihan umum.

Adapun keanggotaan DPD diatur dalam Pasal 252 Undang-undang Nomor 17 Tahun 2014 tentang MPR, DPR, DPD, DPRD yang isinya dinyatakan:

(1) Anggota DPD dari setiap provinsi ditetapkan sebanyak empat (4) orang .

(2) Jumlah anggota DPD tidak lebih dari 1/3 (sepertiga) jumlah anggota DPR.

(3) Keanggotaan DPD diresmikan dengan Keputusan Presiden.

(4) Anggota DPD dalam menjalankan tugasnya berdomisili di daerah pemilihannya dan mempunyai kantor di ibu kota provinsi daerah pemilihannya.

(5) Masa jabatan anggota DPD adalah 5 (lima) tahun dan berakhir pada saat anggota DPD yang baru mengucapkan sumpah/janji.

Terkait dengan tugas dari anggota DPD sebagaimana diuraikan dalam paparan di atas, di dalam realitanya anggota DPD dibantu oleh Staf Ahli.

d. Keberadaan Staf Ahli Dewan Perwakilan Daerah

Beratnya tugas yang harus diemban oleh anggota Dewan Perwakilan Daerah, dalam melaksanakan fungsi dan tugasnya DPD dibantu oleh Staf Ahli yang perekrutannya dilakukan secara tertutup terserah anggota DPD. ${ }^{38}$

Lebih lanjut dikemukakan oleh Deni Martanti bahwa seorang anggota DPD mempunyai tiga (3) orang staf ahli, yang penempatannya 2 orang staf ahli di ibu kota, dan 1 orang yang lain ada di daerah pemilihan anggota DPD yang bersangkutan.

Pola perekrutan staf ahli DPD RI dilakukan:

(1) secara tertutup;

(2) harus lulusan S1 dari semua disiplin ilmu; dan

(3) diikuti dengan proses assessment yang dilakukan oleh Sekretariat Jenderal DPD RI;

(4) SK. Pengangkatan Staf Ahli berlaku selama 1 tahun dan dapat diperpanjang lagi tergantung dari hubungan kmunikasi antara Anggota DPD RI dengan staf ahli yang bersangkutan;

(5) Untuk dapat diangkat menjadi staf ahli harus mendapatkan rekomendasi dari Sekretariat Jenderal DPD, hal ini terkait dengan pemberian honorarium dari staf ahli yang bersangkutan.

Di samping staf ahli sebagaimana dipaparkan di atas, untuk memperlancar fungsi dan tugas DPD, anggota DPD RI juga dibantu oleh 1 orang staf administrasi, yang dulu disebut

${ }^{38}$ Wawancara dengan Deni Martanti, staf ahli Pdt. Rugas Binti, anggota DPD dari Provinsi Kalimantan Tengah, pada tanggal 28 Juli 2016 di Gedung DPD RI, Jakarta. 
sebagai asisten pribadi anggota DPD RI.

Keberadaan staf ahli DPD berpengaruh terhadap kinerja anggota DPD pada saat rapat berlangsung yang diawali dari Rapat Kerja hingga Rapat Dewan Paripurna, seorang syaf ahli harus mengikuti perkembangan terutama pada saat harus pindah dari 1 bidang ke bidang yang lain.

Adapun pola kerja staf ahli harus mengutamakan komunikasi dengan sesame staf ahli karena ada anggota DPD yang still on the track (tetap pada jalannya) dan ada juga anggota DPD yang fleksibel.Sekalipu demikian, untuk mengatasi kekurangan dari staf ahli, seorang staf ahli boleh mengikuti seminar yang diadakan terbuka di lingkungan DPD RI. Secara ekplisit tidak ada keharusan secara resmi bahwa seorang anggota staf ahli harus mengikuti seminarseminar maupun loka karya, namun anggota staf ahli tetap harus mengikuti perkembangan.

Di dalam melaksanakan tugasnya tersebut terdapat kendala yang dihadapi oleh anggota Dewan Perwakilan Daerah yaitu: Kantor DPD RI di Pusat Ibukota Negara RI tidak dapat diakses semua oleh masyarakat yang akan mengajukan aspirasinya. Kondisi ini berbeda dengan kantor perwakilan DPD di daerah yang dapat menyerap aspirasi rakyat, sehingga tidak semua anggota DPD dapat menyelesaikan aspirasi dari masyarakat yang bersangkutan agar sampai kepada menteri yang terkait.

\section{DAFTAR PUSTAKA}

\section{Buku}

Amiruddin dan Zainal Asikin, Pengantar Metode Penelitian Hukum, Raja Grafindo Persada, Jakarta, 2006.

Black Law's Dictionary, Eds. Bryan A. Garnet et.al, West Publishing, St. Paul, 2009

Firmansyah Arifin Dkk. Lembaga Negara dan Sengketa Kewenangan Antarlembaga

Negara, KRHN bekerjasama dengan Mahkamah Konstitusi Republik

Indonesia didukung oleh The Asia Foundation dan USAID, Jakarta, 2005.

Firmansyah Arifin, et. al., Hukum dan Kuasa Konstitusi, KRHN, Jakarta, 2004.

Jimly Asshiddiqie, Format Kelembagaan Negara dan Pergeseran Kekuasaan dalam

UUD 1945, FH UII Press, Yogyakarta, 2004.

Jimly Asshiddiqie, Perkembangan dan Konsolidasi Lembaga Negara Pasca Reformasi, Cetakan kedua, Konstitusi Press, Jakarta, 2006.

Moh Fadli, Jazim Hamidi, dan Mustafa Lutfi, Pembentukan Peraturan Desa Partisipatif (Head To A Good Village Governance), Cetakan pertama, UB Press, Malang, 2011.

Moh Kusnardi dan Bintan R. Saragih, Susunan Pembagian Kekuasaan Menurut Sistem Undang-Undang Dasar 1945, Cetakan ketiga, PT Gramedia, Jakarta, 1983.

Montesquieu, The Spirit of Laws: Dasar-dasar Ilmu Hukum dan Ilmu Politik, (diterjemahkan oleh M. Khoril Anam), Nusa Media, Bandung, 2011.

Ni'matul Huda, Lembaga Negara dalam Masa Transisi Demokrasi, UII Press, Yogyakarta, 2007.

Peter Mahmud Marzuki, Penelitian Hukum, Kencana, Jakarta.

PSHK, Semua Harus Terwakili: Studi Mengenai Reposisi MPR, DPR, dan Lembaga Kepresidenan di Indonesia, PSHK, Jakarta, 2000.

Soerjono Soekanto, Pengantar Penelitian Hukum, UI-Press, Jakarta.

Sukardi, Pembatalan Perda dan Akibat Hukumnya, Disertasi, Universitas Airlangga, 2009. 
Samuel P. Huntington, 1995, Gelombang Demokratisasi Ketiga, (Jakarta: Grafiti).

Alfred Stepan, 1993, "Berbagai Jalur Menuju Demokratisasi: Sejumlah Pertimbangan Teoritis dan Komparatif", dalam Guillermo O'Donnell, Philippe C. Schmitter and Laurence Whitehead (eds.), 1993, Transisi Menuju Demokrasi : Tinjauan Berbagai Perspektif, (Jakarta: LP3ES).

Andreas Schedler, 1998, "What is Democratic Consolidation?", Journal of Democracy, No. 2.

Adam Przeworski et.al. (eds.), 1999, Democracy, Accountability and Representation, (Cambridge: Cambridge University Press).

A. Salman Manggalatung, 2016, Desain Kelembagaan Negara Pasca Amandemen UUD 1945, Gramata Publishing, Bekasi.

Daniel J. Elazar, 1985, "Constitution-making: The Pre-eminently Political Act”, dalam Keith G. Banting, and Richard Simeon, (eds.), 1985, The Politics of Constitutional Change in Industrial Nations: Redesigning The State, (London: The MacMillan Press Ltd.).

Denny Indrayana, 2007, “Komisi Negara Independen: Evaluasi Kekinian dan Tantangan Masa Depan", makalah disampaikan pada "Dialog Nasional Hukum dan Non Hukum: Penataan State Auxillary Bodies Dalam Sistem Ketatanegaraan", diselenggarakan oleh Departemen Hukum dan HAM, Badan Pembinaan Hukum Nasional kerja sama dengan Fakultas Hukum, Universitas Airlangga, Surabaya, 26-29 Juni 2007.

Felipe Aguero, 1995, Soldiers, Civilians, and Democracy: Post-Franco Spain in Comparative Perspective, (Baltimore: The John Hopkins University Press).

Giuseppe di Palma, 1997, Kiat Membangun Demokrasi: Sebuah Esai tentang Transisi Demokrasi, (Jakarta: Yayasan Sumber Agung).

John Higley and Richard Gunther (eds.), 1992, Elites and Democratic Consolidation in Latin America and Southern Europe, (Cambridge: Cambridge University Press).

John P. Wheeler Jr., (ed.), 1961, Salient Issues of Constitutional Revision, (New York: National Municipal League).

Laurence Whitehead, 1989, "The Consolidation of Fragile Democracy", dalam Robert Pastor (ed.), Democracy in the Americas, (New York: Holmes).

Larry Diamond, 2003, Developing Democracy Toward Consolidation, (Yogyakarta: IRE).

Sirajuddin \& Winardi, 2015, Dasar-dasar Hukum Tata Negara Indonesia, Setara Press, Malang,

Sri Soemantri, 1992, Bunga Rampai Hukum Tata Negara Indonesia, Alumni, Bandung.

\section{Peraturan Perundang-Undangan}

Undang-Undang Dasar Negara Republik Indonesia Tahun 1945

Undang-Undang Nomor 17 Tahun 2014 tentang Majelis Permusyawaratan Rakyat, Dewan Perwakilan Rakyat, Dewan Perwakilan Daerah, dan Dewan Perwakilan Rakyat Daerah (UU MD3) 